\title{
Antihyperglycemic Activity of Carthamus oxyacantha growing in Saudi Arabia; an in vitro and in vivo Study
}

\author{
SARA ALDOSSARY* AND HANY EZZAT KHALIL ${ }^{1}$ \\ Department of Pharmaceutical Sciences, College of Clinical Pharmacy, King Faisal University, Al-Ahsa 31982, Saudi Arabia, \\ ${ }^{1}$ Department of Pharmacognosy, Faculty of Pharmacy, Minia University, Minia 61519, Egypt
}

\section{Aldossary et al.: Pharmacological effects of Carthamus oxyacantha}

The main objective of the current study was to investigate the in vitro and in vivo antidiabetic activity of methanol extracts Carthamus oxyacantha leaves and corollas. In vitro antidiabetic assays such as inhibition of $\alpha$-amylase enzyme, non-enzymatic glycosylation of hemoglobin and glucose uptake in yeast cells were carried out. The results of $\alpha$-amylase inhibition assay revealed that the $\mathrm{IC}_{50}$ of methanol extracts of leaf and corolla were almost same (58.5 and $57.1 \mu \mathrm{g} / \mathrm{ml}$, respectively) when compared with positive control acarbose $(45.3 \mu \mathrm{g} / \mathrm{ml})$. Glycosylation of hemoglobin was inhibited and the methanol extract of corolla showed an $\mathrm{IC}_{50}$ value of $61.7 \mu \mathrm{g} / \mathrm{ml}$, while methanol extract of the leaf showed $93.9 \mu \mathrm{g} / \mathrm{ml}$ when compared to the positive control, $\alpha$-tocopherol $(35.4 \mu \mathrm{g} / \mathrm{ml})$. On the other hand, the percent glucose uptake in yeast cells caused by methanol extracts of leaf and corolla was distinctly greater when compared to that of metformin. In vivo antidiabetic study revealed that the two methanol extracts at a dose of $200 \mathrm{mg} / \mathrm{kg}$ reduced the fasting plasma glucose level $(94.6 \pm 4.4$ and $102.1 \pm 5.5 \mathrm{mg} / \mathrm{dl}$, respectively) when compared to that of glibenclamide (79.4 \pm $3.4 \mathrm{mg} / \mathrm{dl}, \mathrm{p}<\mathbf{0 . 0 0 1})$. The results from this study indicated that Carthamus oxyacantha leaf and corolla methanol extracts exhibited considerable in vitro and in vivo antidiabetic activities, which would make Carthamus oxyacantha a potential antidiabetic agent.

Key words: Carthamus, antidiabetic, $\alpha$-amylase, hemoglobin, yeast cells, streptozotocin

Natural products have aided humans since long ages as plants are considered untapped resources of medicinally essential bioactive constituents ${ }^{[1]}$. On the other hand, the usage of synthetic drugs may cause several side effects such as vomiting, diarrhea, fluid retention and allergic reactions ${ }^{[2]}$ as well as could bring about possible resistance of many microbes. Moreover, synthetic drugs are usually more expensive. Hence, natural products could serve to play a significant role in the development of cheaper and effective alternate drugs. The constituents present in medicinal plants are used therapeutically as antidiabetic, chemotherapeutic and for a plethora of other applications ${ }^{[3]}$. Diabetes mellitus (DM) is a metabolic disease manifested by elevated levels of glucose in blood. It can be generally divided into diabetes mellitus type I and diabetes mellitus type II (T2DM). T2DM represents about 90$95 \%$ of all cases of diabetes ${ }^{[4]}$. T2DM is considered one of the main international health concerns. T2DM affects around 422 million people all over the world ${ }^{[5]}$. Prediabetes and diabetes prevalence and complications are growing in a bothersome way. By 2035, it is anticipated that about 592 million people will suffer from $\mathrm{DM}^{[6]}$. The treatment of $\mathrm{T} 2 \mathrm{DM}$ is

This is an open access article distributed under the terms of the Creative Commons Attribution-NonCommercial-ShareAlike 3.0 License, which allows others to remix, tweak, and build upon the work non-commercially, as long as the author is credited and the new creations are licensed under the identical terms

Accepted 29 May 2019

Revised 16 January 2019

Received 03 December 2018

Indian J Pharm Sci 2019;81(4):785-790 
currently achieved through conventional drugs that are effective in controlling diabetes to some extent but are accompanied with some undesirable effects ${ }^{[7]}$. There are some enzymes like $\alpha$-amylase and other glucose uptake mechanisms by cells could manage the level of blood glucose in our body and maintain the blood sugar level at physiological level ${ }^{[8]}$.

Asteraceae is one of the largest families of flowering plants. It includes more than 1000 genera and about 10000 species distributed over all parts of the world ${ }^{[2]}$. The genus Carthamus, one of family Asteraceae, includes 25 species. Reviewed literature showed that many of Carthamus species have been used to treat many diseases and complaints such as, cough, typhoid fever, throat disorders, cardiovascular problems, swelling, menstrual disorders, antiinflammatory, antioxidant, calcium antagonist and anticoagulant, and also used in folk medicine as sedative and anticancer herbal product ${ }^{[9]}$. The flowers, seeds and oils of Carthamus oxyacantha (C. oxyacantha), have been reported to possess a diversity of biological activities ranging from local to systemic actions ${ }^{[8]}$. The seeds of C. oxyacantha are used for treating diabetes in some parts of the Pakistan. However, there is no detailed record available about this important potential effect of this plant ${ }^{[10]}$. Therefore, the current study was conducted to assess the in vitro antidiabetic potential of leaves and corollas of $C$. oxyacantha by studying their $\alpha$-amylase inhibitory activity, effects on inhibition of glycosylation of hemoglobin and glucose uptake by yeast cells. A confirmatory in vivo study was also conducted with these extracts of $C$. oxyacantha in streptozotocin (STZ)-induced diabetic rats to evaluate their potential hypoglycaemic effects.

C. oxyacantha was collected from Al-hasa, eastern region of Saudi Arabia. Leaves and corollas of plant were collected and air-dried according to the standard protocols. The plant under investigation was authenticated at the El-Zohria Botanical Garden, Giza, Egypt. A voucher specimen was kept in the Department of Pharmaceutical Sciences, College of Clinical Pharmacy, King Faisal University, Al-Hasa, Saudi Arabia (02-16-Apr-CO).

The powdered air-dried leaves and corollas of C. oxyacantha, 300.0 and $100.0 \mathrm{~g}$, respectively were exhaustively extracted twice (each for $5 \mathrm{~d}$ ) using 31 of $70 \% \mathrm{MeOH} / \mathrm{H}_{2} \mathrm{O}$ applying cold maceration technique at room temperature to protect the potential active ingredients from being destroyed. The solvent mixture was removed through distillation under vacuum using a rotavapor and the dried extracts were directly freezedried to give the total methanol extracts of the leaf and the corolla weighting 22.4 and $4.1 \mathrm{~g}$, respectively, which were stored at $-20^{\circ}$ for the next steps ${ }^{[9]}$.

Male Wistar rats weighing 150-210 g were kept in quarantine for $2 \mathrm{w}$ under standard husbandry conditions $\left(27^{\circ}\right.$, relative humidity $\left.65 \pm 10 \%\right)$ under $12 \mathrm{~h}$ dark and light cycle and were given standard food and water $a d$ libitum $^{[11]}$. All of the experiments done in this study were approved by the Animal Ethics Committee of King Faisal University (KFU-REC/2018-10-03). Acarbose, glibenclamide, STZ, metformin, gentamycin, $\alpha$-amylase from porcine pancreas, hemoglobin porcine and $\alpha$-tocopherol were purchased from Sigma Aldrich (ST. Louis. Mo, USA). Solvents used for extraction and assays were all of analytical grade.

The assay mixture was prepared to contain $0.02 \mathrm{M}$ sodium phosphate buffer $(200 \mu \mathrm{l}), \alpha$-amylase enzyme $(20 \mu \mathrm{l}, 2 \mathrm{unit} / \mathrm{ml})$ together with different plant extracts in the range of concentrations $20-100 \mu \mathrm{g} / \mathrm{ml}$. Then, it was incubated for $10 \mathrm{~min}$ at room temperature followed by the addition of $200 \mu \mathrm{l}$ of $1 \%$ starch suspension to all the tubes containing reaction mixture. The reaction was later terminated by the addition of $400 \mu$ of 3,5-dinitro salicylic acid colour reagent. Then the tubes were kept in boiling water bath for $5 \mathrm{~min}$, cooled to room temperature and diluted with $15 \mathrm{ml}$ of distilled water. The absorbance of each reaction mixture was measured at $540 \mathrm{~nm}$. Control mixture reactions were also prepared accordingly without addition of extracts of plant under investigation and were compared with the test samples containing concentration of different plant extracts $(20-100 \mu \mathrm{g} / \mathrm{ml})$ freshly prepared in dimethyl sulfoxide. The results were expressed as \% inhibition of activity calculated using the following Eqn., \% inhibition = (Abs(control)-Abs(extract))/Abs(control) $\times 100$, where, Abs (control) is the absorbance of the control reaction (containing all reagents except the test sample) and Abs (sample) is the absorbance of different plant extracts ${ }^{[12,13]}$. The $\mathrm{IC}_{50}$ values (concentration causing $50 \%$ inhibition of the enzyme activity) of the plant extracts were determined. Acarbose, which is used to treat T2DM, was employed as a positive control in the concentrations range of 20 to $100 \mu \mathrm{g} / \mathrm{ml}^{[14]}$. Experiments were performed in triplicate.

Solutions of glucose $(2 \%)$, hemoglobin $(0.06 \%)$ and gentamycin $(0.02 \%)$, were freshly prepared in phosphate buffer $(0.01 \mathrm{M}, \mathrm{pH} 7.4)$. One milliliter of 
each of above mentioned solution was mixed. One milliliter of each concentration of different plant extracts $(20-100 \mu \mathrm{g} / \mathrm{ml})$ was added to the prepared mixture. Then, the reaction tubes were incubated in a dark place at room temperature for three days. The degree of glycosylation of hemoglobin was obtained colorimetrically at $520 \mathrm{~nm}$ where the percent inhibition was calculated applying the formula, $\%$ inhibition = $($ Abs (control)-Abs $($ extract $)) /($ Abs $($ control $)) \times 100$. The $\mathrm{IC}_{50}$ values of the plant extracts were determined. $\alpha$-Tocopherol was used as a standard drug ${ }^{[12-14]}$. Experiments were carried out in triplicate.

Commercial baker's yeast (Saccharomyces cerevisiae) was prepared for experiment by repeated washing and centrifugation $(3000 \times \mathrm{g}, 5 \mathrm{~min})$ in distilled water until the supernatant fluids were clear. A concentration of $10 \%(\mathrm{v} / \mathrm{v})$ suspension of supernatant fluid was prepared. Concentrations of different plant extracts (20-100 $\mu \mathrm{g} / \mathrm{ml})$ were added to $1 \mathrm{ml}$ of freshly prepared 5,10 and $25 \mathrm{mM}$ glucose solution and incubated for $10 \mathrm{~min}$ in an incubator at $37^{\circ}$. Reaction was initiated by the addition of $100 \mu \mathrm{l}$ of freshly prepared yeast suspension, vortexed and further incubated at $37^{\circ}$ for $1 \mathrm{~h}$. Then the tubes containing the reaction mixture were centrifuged at $2500 \times \mathrm{g}$, for $5 \mathrm{~min}$ and the remaining glucose was determined in the supernatant. The \% increase in glucose uptake by yeast cells was calculated according to the formula, glucose uptake $\%=($ Abs (control)-Abs (extract) $) /$ $(\mathrm{Abs}($ control $)) \times 100^{[12,15-18]}$. Metformin was used as positive contro[ ${ }^{[12]}$. Measurements were carried out in triplicates.

Acute toxicity testing was performed for both leaves and corollas extracts, were studied where the rats received ascending oral doses up to $2000 \mathrm{mg} / \mathrm{kg}$ of each extract and signs and symptoms of toxicity were observed for the next $48 \mathrm{~h}^{[19]}$.

Diabetes was induced by an intraperitoneal (ip) injection of STZ dissolved in $0.1 \mathrm{M}$ cold citrate buffer $(\mathrm{pH}=4.4)$ at a dose of $60 \mathrm{mg} / \mathrm{kg}$. On the third day after STZ injection, fasted blood glucose levels were measured by hand-held glucose monitoring (Bayer Contour). Only rats with serum glucose levels of $190-200 \mathrm{mg} / \mathrm{dl}$ were selected and considered diabetic animals ${ }^{[20]}$. The animals were segregated into 5 groups of 6 rats each. Group I served as normal control rats, administered drinking water and $0.1 \mathrm{M}$ cold citrate buffer ( $\mathrm{pH}=4.4$ ) daily for $12 \mathrm{~d}$; group II comprised of diabetic control rats, administered drinking water daily for $12 \mathrm{~d}$; group III diabetic rats were administered leaf extract $(200 \mathrm{mg} / \mathrm{kg}$ ) for $12 \mathrm{~d}$; group IV diabetic rats were administered corolla extract $(200 \mathrm{mg} / \mathrm{kg})$ for $12 \mathrm{~d}$; and group $\mathrm{V}$ diabetic rats were administered glibenclamide $(0.25 \mathrm{mg} / \mathrm{kg})$ for $12 \mathrm{~d}$. The fasting glucose levels were determined on $\mathrm{d} 1,5$, and 12 of extracts administration ${ }^{[19-21]}$.

Data were expressed as mean $\pm \mathrm{SE}$. To analyse the differences between groups, statistical analysis was performed using the one-way ANOVA followed by post-hoc Tukey's test using a computer soft program SPSS v.20.

The in vitro $\alpha$-amylase activity measurements demonstrated that both leaf and corolla methanol extracts of $C$. oxyacantha has the potential to inhibit $\alpha$-amylase activity. $\alpha$-Amylase inhibitory potential was compared using the $\mathrm{IC}_{50}$ values (Table 1). It was found that the $\alpha$-amylase inhibitory activity of both leaf and corolla extracts were almost the same $\left(\mathrm{IC}_{50} 58.5\right.$ and $57.1 \mu \mathrm{g} / \mathrm{ml}$, respectively). Acarbose, the positive standard showed an $\mathrm{IC}_{50}$ value of $45.3 \mu \mathrm{g} / \mathrm{ml}$ under similar conditions.

Inhibition of non-enzymatic glycosylation of hemoglobin produced by both leaf and corolla extracts of $C$. oxyacantha were compared using the $\mathrm{IC}_{50}$ values (Table 2). Corolla methanol extract showed an $\mathrm{IC}_{50}$ value of $61.7 \mu \mathrm{g} / \mathrm{ml}$ compared to the positive control, alpha-tocopherol's $\mathrm{IC}_{50}$ value of $35.4 \mu \mathrm{g} / \mathrm{ml}$. Leaf methanol extract inhibited with a $\mathrm{IC}_{50}$ of $93.9 \mu \mathrm{g} / \mathrm{ml}$.

The effect of both leaf and corolla extracts of C. oxyacantha on transportation of glucose through the yeast cell membrane was demonstrated in an in vitro model comprising of freshly prepared mixture of yeast cells and glucose solution of different strengths $(5,10,25 \mathrm{mM})$ in the presence of extracts at different concentrations ranging from 20 to $100 \mu \mathrm{g} / \mathrm{ml}$ (Table 3).

TABLE 1: $\alpha$-AMYLASE INHIBITORY EFFECT OF C. OXYACANTHA EXTRACTS

\begin{tabular}{lccc}
\hline \multicolumn{4}{c}{ Percent inhibition } \\
\hline $\begin{array}{l}\text { Concentration } \\
(\mu \mathrm{g} / \mathrm{ml})\end{array}$ & $\begin{array}{c}\text { Leaf } \\
\text { methanol } \\
\text { extract }\end{array}$ & $\begin{array}{c}\text { Corolla } \\
\text { methanol } \\
\text { extract }\end{array}$ & Aacarbose \\
\hline 20 & $22.7 \pm 1.0$ & $23.9 \pm 1.1$ & $32.2 \pm 1.1$ \\
40 & $37.7 \pm 1.3$ & $33.7 \pm 1.4$ & $43.8 \pm 1.3$ \\
60 & $57.2 \pm 1.1$ & $60.4 \pm 1.3$ & $64.9 \pm 2.3$ \\
80 & $63.8 \pm 1.0$ & $66.8 \pm 0.9$ & $75.5 \pm 1.4$ \\
100 & $73.5 \pm 0.8$ & $75.1 \pm 1.1$ & $81.1 \pm 1.3$ \\
$\mathrm{IC}_{50}(\mu \mathrm{g} / \mathrm{ml})$ & 58.5 & 57.1 & 45.3 \\
\hline
\end{tabular}


No toxicity or death was observed in the experimental rats. Hence $200 \mathrm{mg} / \mathrm{kg}(1 / 10$ of the $2000 \mathrm{mg} / \mathrm{kg})$ was selected as a maximum safety dose. The effects of both leaf and corolla methanol extracts of $C$. oxyacantha on fasting blood glucose levels of diabetic rats were presented in Table 4. In diabetic rats, as shown in Table 4, both leaf and corolla methanol extracts of C. oxyacantha and glibenclamide produced significant time-dependent hypoglycaemic activity, compared with the diabetic control group at each time point $(\mathrm{p}<0.001)$.

$\alpha$-Amylase is one of the enzymes responsible for the hydrolysis of $\alpha$-oriented bonds of polysaccharides and oligosaccharides such as starch, glycogen and other macromolecules of $\alpha$-bond linked monosaccharides to disaccharides and finally to glucose ${ }^{[22-25]}$. Both leaf and corolla methanol extracts of $C$. oxyacantha showed promising $\alpha$-amylase inhibitory assay, which suggested that $C$. oxyacantha might be effective in slowing down hydrolysis of starch to reduce glucose availability.

In vitro non-enzymatic glycosylation of hemoglobin method is one of the important assays to judge control of diabetic state. The hemoglobin present in RBCs has an affinity to bind to glucose. The greater the glucose level in blood, more amount of glucose-bound (called glycosylated) hemoglobin will be formed. Such glucose

TABLE 2: EFFECT OF C. OXYACANTHA EXTRACTS ON NON-ENZYMATIC GLYCOSYLATION OF HEMOGLOBIN

\begin{tabular}{lccc}
\hline \multicolumn{4}{c}{ Percent inhibition } \\
\hline $\begin{array}{l}\text { Concentration } \\
(\mu \mathrm{g} / \mathrm{ml})\end{array}$ & $\begin{array}{c}\text { Leaf } \\
\text { methanol } \\
\text { extract }\end{array}$ & $\begin{array}{c}\text { Corolla } \\
\text { methanol } \\
\text { extract }\end{array}$ & a-Tocopherol \\
\hline 20 & $14.5 \pm 1.1$ & $28.8 \pm 0.6$ & $38.8 \pm 0.5$ \\
40 & $22.4 \pm 0.9$ & $35.4 \pm 1.0$ & $49.3 \pm 0.6$ \\
60 & $38.9 \pm 1.3$ & $49.5 \pm 1.3$ & $71.6 \pm 0.6$ \\
80 & $43.5 \pm 0.8$ & $62.7 \pm 1.2$ & $81.0 \pm 1.0$ \\
100 & $50.9 \pm 1.1$ & $68.8 \pm 0.7$ & $82.7 \pm 1.6$ \\
$\mathrm{IC}_{50}(\mu \mathrm{g} / \mathrm{ml})$ & 93.9 & 61.7 & 35.4 \\
\hline
\end{tabular}

Values were expressed as mean \pm SE (standard error) of $n=3$ independent experiments hemoglobin association is to some extent stable and stays for 1-2 mo (the life-span of red blood corpuscles) ${ }^{[25,26]}$. Consequently presence of higher concentration of glycosylated hemoglobin is a sure guide to the higher concentration of glucose in the blood. Normally, the percentage of glycated hemoglobin should not be exceeding $12 \%$. The current study demonstrated good activity of corollas methanol extract (half that of positive control, $\alpha$-tocopherol) in preventing such binding of glucose to surface proteins of erythrocytes. On the other hand, leaves methanol extract expressed low $\mathrm{IC}_{50}$ when compared to positive control.

In the glucose uptake in yeast cells model, transport of glucose across yeast cell membrane has been used efficiently as in vitro screening method for evaluation of hypoglycemic effect of natural derived products ${ }^{[17,27,28]}$. After treating the yeast cells with both leaf and corolla methanol extracts of $C$. oxyacantha, the results revealed that corolla methanol extract exhibited activity at all levels of glucose concentrations used. The minimum increase was $15.3 \pm 1.1 \%$ at $20 \mu \mathrm{g} / \mathrm{ml}$ and maximum increase was $49.9 \pm 1.6 \%$ at $100 \mu \mathrm{g} / \mathrm{ml}$ concentration. On the other hand, leaf methanol extract showed lesser activation when compared to that of corolla extract at all glucose concentrations. The minimum increase was $3.7 \pm 0.1 \%$ at $20 \mu \mathrm{g} / \mathrm{ml}$ and the maximum increase was $21.5 \pm 1.5 \%$ at $100 \mu \mathrm{g} / \mathrm{ml}$ concentration. The results clearly indicated that both leaf and corolla methanol extracts had noticeable efficacy in increasing the glucose uptake by yeast cells as compared to the standard drug metformin $19.1 \pm 1.0 \%$ at $20 \mu \mathrm{g} / \mathrm{ml}$ and $91.4 \pm 0.7 \%$ at $100 \mu \mathrm{g} / \mathrm{ml}$.

The fundamental mechanism underlying elevated blood sugar in DM involves over-production and decreased utilization of glucose by the tissues. In the current study, the difference observed between the initial and final fasting plasma glucose levels of different groups of rats under investigation, revealed a significant elevation in blood glucose in the diabetic control group as compared to normal animals, at the end of the

TABLE 3: EFFECT OF C. OXYACANTHA ON GLUCOSE UPTAKE BY YEAST CELLS

\begin{tabular}{|c|c|c|c|c|c|c|c|c|c|}
\hline \multirow{3}{*}{$\begin{array}{l}\text { Test concentration } \\
(\mu \mathrm{g} / \mathrm{ml})\end{array}$} & \multicolumn{9}{|c|}{ Percent glucose uptake at different glucose concentrations } \\
\hline & \multicolumn{3}{|c|}{ Leaf methanol extract } & \multicolumn{3}{|c|}{ Corolla methanol extract } & \multicolumn{3}{|c|}{ Metformin } \\
\hline & $5 \mathrm{mM}$ & $10 \mathrm{mM}$ & $25 \mathrm{mM}$ & $5 \mathrm{mM}$ & $10 \mathrm{mM}$ & $25 \mathrm{mM}$ & $5 \mathrm{mM}$ & $10 \mathrm{mM}$ & $25 \mathrm{mM}$ \\
\hline 20 & $9.5 \pm 1.1$ & $4.9 \pm 0.9$ & $3.7 \pm 0.1$ & $18.9 \pm 0.8$ & $16.7 \pm 1.4$ & $15.3 \pm 1.1$ & $24.3 \pm 0.3$ & $22.1 \pm 0.7$ & $19.1 \pm 1.0$ \\
\hline 40 & $13.5 \pm 1.6$ & $11.7 \pm 0.7$ & $8.5 \pm 0.5$ & $21.9 \pm 0.8$ & $20.3 \pm 1.3$ & $15.8 \pm 1.6$ & $53.1 \pm 0.4$ & $49.1 \pm 0.3$ & $38.0 \pm 0.8$ \\
\hline 60 & $16.1 \pm 0.6$ & $12.7 \pm 0.8$ & $10.8 \pm 1.0$ & $30.6 \pm 0.6$ & $20.7 \pm 1.8$ & $16.4 \pm 1.9$ & $78.0 \pm 0.3$ & $74.9 \pm 0.5$ & $61.4 \pm 0.9$ \\
\hline 80 & $18.4 \pm 0.4$ & $13.3 \pm 0.3$ & $8.4 \pm 0.6$ & $40.2 \pm 2.0$ & $28.9 \pm 0.7$ & $28.4 \pm 1.0$ & $83.6 \pm 0.6$ & $78.4 \pm 1.4$ & $70.9 \pm 0.7$ \\
\hline 100 & $21.5 \pm 1.5$ & $12.4 \pm 1.1$ & $11.8 \pm 1.0$ & $49.9 \pm 1.6$ & $33.2 \pm 1.2$ & $29.7 \pm 2.0$ & $91.4 \pm 0.7$ & $84.9 \pm 0.9$ & $80.2 \pm 0.4$ \\
\hline
\end{tabular}

Values were expressed as mean \pm SE (standard error) of $n=3$ independent experiments 


\begin{tabular}{|c|c|c|c|}
\hline \multicolumn{4}{|c|}{ Fasting plasma glucose concentration (mg/dl) } \\
\hline Groups & Day 1 & Day 5 & Day12 \\
\hline I- Normal control & $79.9 \pm 1.2$ & $80.9 \pm 0.8$ & $81.6 \pm 1.1$ \\
\hline II- Diabetic control (streptozotocin, 55 mg/kg) & $196.8 \pm 2.4$ & $198.18 \pm 1.6$ & $211.3 \pm 2.5$ \\
\hline III- Diabetic+leaf methanol extract $(200 \mathrm{mg} / \mathrm{kg})$ & $200.3 \pm 2.6$ & $114.2 \pm 1.8^{*}$ & $94.56 \pm 1.8^{*}$ \\
\hline IV- Diabetic+corolla methanol extract $(200 \mathrm{mg} / \mathrm{kg})$ & $192.4 \pm 1.3$ & $130.2 \pm 1.9^{*}$ & $102.1 \pm 2.3^{*}$ \\
\hline V- Diabetic+glibenclamide $(0.25 \mathrm{mg} / \mathrm{kg})$ & $196.5 \pm 1.5$ & $91.38 \pm 1.1^{*}$ & $79.4 \pm 1.4^{*}$ \\
\hline
\end{tabular}

Values were expressed as mean \pm SE (standard error), $n=6$, *significantly different from diabetic control $(p<0.001)$

twelve-day experimental period. When leaf and corolla methanol extracts of $C$. oxyacantha were administered to diabetic rats, a decrease in plasma glucose level was observed after $12 \mathrm{~d}$ (Table 4). During the study it was found that both extracts significantly controlled the blood glucose level in STZ-induced diabetic rats as compared to the diabetic control group (Table 4). However, the corolla methanol extract showed greater antidiabetic activity as compared to the leaf methanol extract.

The in vitro examinations conducted revealed a substantial $\alpha$-amylase inhibitory activity, a reduction in the glycosylation of hemoglobin and an increase in the glucose uptake by the yeast cell by both the leaf and the corolla methanol extracts of $C$. oxyacantha. The in vivo studies also showed that both extracts significantly controlled the blood glucose level diabetic rats. It could therefore be conclude from these results that $C$. oxyacantha could serve as a therapeutic agent or as a potential source of novel antidiabetic molecules.

\section{Acknowledgement:}

The authors are grateful to Dr. Ahmed A. Mohamed, Clinical lecturer, Department of Pharmacy Practice, College of Clinical Pharmacy, King Faisal University, Saudi Arabia for his help in statistical analysis. Authors also wish to thank Dr. Mamdouh Shokry, Director, El-Zohria Botanical Garden, Giza, Egypt for authenticating the plant material. The authors acknowledge the Deanship of Scientific Research at King Faisal University for financial support under Nasher Track (Grant No. 186250).

\section{Conflict of interest:}

Authors declare no conflicts of interest.

\section{Financial support and sponsorship:}

This work was supported and funded by the deanship of scientific research (NO 186250) at King Faisal University.

\section{REFERENCES}

1. Nair SS, Kavrekar V, Mishra A. Evaluation of in vitro antidiabetic activity of selected plant extracts. Int J Pharm Sci Invent 2013;2(4):12-9.

2. Ahmad M, Waheed I, Khalil-ur-Rehman M, Niaz U, Hassan SS. A review on Carthamus oxycantha. Pak J Pharm 2007;20(23):1.

3. Eze ED, Mohammed A, Musa KY, Tanko Y. Evaluation of effect of ethanolic leaf extract of Mucuna pruriens on blood glucose levels in alloxan-induced diabetic wistar rats. Asian J Med Sci 2012;4(1):23-8.

4. Zhao BT, Le DD, Nguyen PH, Ali MY, Choi JS, Min BS, et al. PTP1B, $\alpha$-glucosidase, and DPP-IV inhibitory effects for chromene derivatives from the leaves of Smilax china L. Chem Biol Interact 2016;253:27-37.

5. WHO, 2016. World Health Day 2016: WHO Calls for Global Action to Halt Rise in and Improve Care for People with Diabetes. Available at: http:/www.who.int/mediacentre/news/ releases/2016/world-health-day/en/.

6. Seong SH, Roy A, Jung HA, Jung HJ, Choi JS. Protein tyrosine phosphatase $1 \mathrm{~B}$ and $\alpha$-glucosidase inhibitory activities of Pueraria lobata root and its constituents. J Ethnopharmacol 2016;194:706-16.

7. Jyothi KS, Hemalatha P, Challa S. Evaluation of $\alpha$-amylase inhibitory potential of three medicinally important traditional wild food plants of India. Int J Green Pharm 2011;5(2):95.

8. Majumder P, Mazumder S, Chakraborty M, Chowdhury SG, Karmakar S, Haldar PK. Preclinical evaluation of Kali Haldi (Curcuma caesia): a promising herb to treat type-2 diabetes. Orient Pharm Exp Med 2017;17(2):161-9.

9. Khalil HE, Al Ahmed A. Phytochemical Analysis and Free Radical Scavenging Activity of Carthamus oxyacantha growing in Saudi Arabia: A Comparative Study. Int J Pharm Sci Rev Res 2017;45(1):51-5.

10. Bukhsh E, Malik SA, Ahmad SS, Erum S. Hepatoprotective and hepatocurative properties of alcoholic extract of Carthamus oxyacantha seeds. Afr J Plant Sci 2014;8(1):3441.

11. Sobeh M, Mahmoud MF, Abdelfattah MAO, El-Beshbishy HA, El-Shazly AM, Wink M. Hepatoprotective and hypoglycemic effects of a tannin rich extract from Ximenia americana var. caffra root. Phytomedicine 2017;33:36-42.

12. Muchandi AA, Jadhav AS, Patil SB, Patil SA, Jadhav NB. Antioxidant and In vitro Antidiabetic Activity of Methanol Extract of Piper cubeba L.A review. Int Res J Pharm Med 2017;8(1):81-7.

13. Santhiya N, Priyanga S, Hemmalakshmi S, Devaki K. Phytochemical analysis, Antiinflammatory activity, in vitro antidiabetic activity and GC-MS profile of Erythrina variegata L. bark. J Appl Pharm Sci 2016;6(07):147-55. 
14. Phillips P, Karrasch J, Scott R, Wilson D, Moses R. Acarbose improves glycemic control in overweight type 2 diabetic patients insufficiently treated with metformin. Diabetes Care 2003;26(2):269-73.

15. Chaudhari MG, Joshi BB, Mistry KN. In vitro anti-diabetic and anti-inflammatory activity of stem bark of Bauhinia purpurea. Bull Pharm Med Sci 2013;1(2):139-50.

16. Das SK, Samanta L, Thatoi H. In vitro A ntidiabetic and Antioxidant Potentials of Leaf and Stem Bark Extracts of a Mangrove Plant, Xylocarpus granatum. J Herbs Spices Med Plants 2016;22(2):105-17.

17. Vijayalakshmi K, Selvaraj IC, Sindhu S, Arumugam P. In vitro investigation of antidiabetic potential of selected traditional medicinal plants. Int J Pharmacogn Phytochem Res 2015;6(4):856-61.

18. Bhutkar M, Bhise S. In vitro hypoglycemic effects of Albizzia lebbeck and Mucuna pruriens. Asian Pac J Trop Biomed 2013;3(11):866-70.

19. Sharma U, Sahu RK, Roy A, Golwala D. In vivo antidiabetic and antioxidant potential of Stephania hernandifolia in streptozotocin-induced-diabetic rats. J Young Pharm 2010;2(3):255-60.

20. Wan LS, Chen CP, Xiao ZQ, Wang YL, Min QX, Yue Y, et al. In vitro and in vivo anti-diabetic activity of Swertia kouitchensis extract. J Ethnopharmacol 2013;147(3):622-30.

21. Ezzat SM, Abdel Motaal A, El Awdan SAW. In vitro and in vivo antidiabetic potential of extracts and a furostanol saponin from Balanites aegyptiaca. Pharm Biol 2017;55(1):1931-6.

22. Suganya G, Sampath KP, Dheeba B, Sivakumar R. In vitro antidiabetic, antioxidant and anti-inflammatory activity of Clitoria ternatea. L. Int J Pharm Pharm Sci 2017;6(7):342-7.

23. Kotowaroo MI, Mahomoodally MF, Gurib-Fakim A, Subratty AH. Screening of traditional antidiabetic medicinal plants of mauritius for possible $\alpha$-amylase inhibitory effects in vitro. Phytother Res 2006;20(3):228-31.

24. Abirami N, Natarajan B, Sagadevan E. Phytochemical investigation and in vitro evaluation of hypoglycemic potential of Grewia hirsuta. Int J Pharm Bio Sci 2014;5(1):76-83.

25. Radhika S, Senthil KR, Sindhu S, Sagadevan E, Arumugam P. Phytochemical investigation and evaluation of antihyperglycemic potential of Premna corymbosa. Int $\mathrm{J}$ Pharm Pharm Sci 2013;5(4):352-6.

26. Daksha GU, Chandrashekar KS, Pai GI. In vitro antidiabetic activity of pentacyclictritrpenoids and fatty acid esters from Bauhinia purpurea. Int J Pharmacol Pharm Technol 2013;2(1):25-8.

27. Karpagasundari C, Kulothungan S. In vitro Antidiabetic Activity of Physalis minima Methanol Leaves Extract. Int J Res Plant Sci 2015;5(4):37-40.

28. Pitchaipillai R, Ponniah T. In vitro Antidiabetic Activity of Ethanolic Leaf Extract of Bruguiera cylindrica L. Glucose Uptake by Yeast Cells Method. Int Biol Biomed J 2016;2:171-5. 